\title{
Is There An Industry Effect in Executive Compensation? Evidence from Aerospace/Defense and Leisure/Hospitality Industry
}

\author{
Confidence W. Amadi ${ }^{1} \&$ Felicia Y. Amadi ${ }^{1}$ \\ ${ }^{1}$ Department of Business \& Economics, Elizabeth City State University, Elizabeth City, USA \\ Correspondence: Confidence W. Amadi, Department of Business \& Economics, Elizabeth City State University, \\ Elizabeth City, USA. E-mail: cwamadi@ecsu.edu
}

Received: June 18, 2017

Accepted: July 5, 2017

Online Published: July 18, 2017

doi:10.5539/ijbm.v12n8p51

URL: https://doi.org/10.5539/ijbm.v12n8p51

\begin{abstract}
The objective of this study is to compare the executive compensation of two industries that are diametrically opposites in terms of dependence on government: The Aerospace/Defense industry versus Leisure/Hospitality industry. The financial crisis brought the issue of the executive compensation to the attention of government. Congress has often tried to control executive compensation through mandated public disclosures of private contracts, restrictive tax policy, and direct interference with corporate governance. Recent studies show a reduction in donations to nonprofits subsequent to disclosure of high executive compensation. In the same light, since governments are the primary customers of defense industry, we suspect that the issue of high levels of executive compensation will factor into contract negotiations. The study finds a negative relationship, albeit weak, between the Aerospace/Defense industry variable and executive compensation as compared to the Leisure/Hospitality industry.
\end{abstract}

Keywords: CEO Compensation, Firm Performance, CEO/Chairman Duality, Aerospace/Defense Industry, Leisure/Hospitality Industry

\section{Introduction}

There is extensive literature on the executive compensation focusing on the factors that explain the variation in its level across firms. The financial crisis brought the issue of the executive compensation to the attention of government. Congress has often tried to control executive compensation through "mandated public disclosures of private contracts, restrictive tax policy, and direct interference with corporate governance" (Willard, 2010). To them, executive compensation is only costs that needs to be reined in regardless of the wealth created for the shareholders or the impact of their decisions on national income and employment. Since congress is so antiexecutive compensation, the question becomes, do they control or affect the compensation of firms that are heavily dependent on government, Aerospace and Defense Industry? The objective of this study is to compare the executive compensation of two industries that are diametrically opposites in terms of dependence on government: the Aerospace/Defense industry versus Leisure/Hospitality industry. Balsam and Harris (2013) report a reduction in donations to nonprofits subsequent to disclosure of high executive compensation. In the same light, since governments are the primary customers of defense industry, we suspect that the issue of high levels of executive compensation will factor into contract negotiations.

The Aerospace/Defense industry (ADI) serves the market for the production, sales, and service of commercial aircraft and the market for the nation's need for military weapons and systems designed to operate on land, sea, and in the air. It also includes the production of general aircraft and space vehicles such as satellites, for both military and commercial use (Valueline, 2014). ADI is a highly concentrated market that sells mainly to governments and demand is driven by military budgets, the possibility of international warfare, and airline traffic (Reportlinker, 2014).

The Leisure and Hospitality Industry (LHI) consists of two sectors: Arts, Entertainment, and Recreation, and Accommodation and Food Services (BLS, 2014). The Arts, Entertainment and Recreation sector operate facilities or provide services to meet varied cultural, entertainment, and recreational interests of its patrons (BLS, 2014). The Accommodation and Food Service sector comprises establishments that provide its customers with lodging, and/or preparing meals, snacks, and beverages for immediate consumption (BLS, 2015). LHI industry "are highly sensitive to economic and competitive market conditions, and are capital, management, marketing, 
personnel, energy, maintenance, and technology intensive (PWC, 2015).

Given the difference between these two industries, this paper seeks to examine the differences between the executive compensations in the light of market forces and regulatory forces that are the primary drivers of the fortunes of these industry. The rest of the paper is organized as follows: section II is a brief literature review of the factors that influence executive compensation. Section III provides the data and methodology, section IV, the results and analysis and section $\mathrm{V}$ is the conclusion and limitations.

\section{Brief Literature Review}

Boerner (2013), provides an overview of the current public dialogue on corporate executive compensation. Boerner reports on the shift from the impact of excessive executive compensation on shareholders wealth to the current debate on the discrepancy and gap between the wages of the average worker and the executive team. The involvement of institutional and activist shareholder groups such as the Interfaith Center on Corporate Responsibility (ICCR) have largely been responsible for the government and society's focus on executive compensation.

Ims, Pedersen and Zsolnai (2014) discuss the potential negative impact of traditional "one-dimensional economic incentives" on existential, social, and ecological values on responsible business conduct. Their argument ignores the role of supplies of capital and the market based economy. The interest of the shareholders is the primary function of management. The social implications of their decision is left for the consumers of the firm's goods and services to decide. Moreover, the level of an executive's compensation is contractual where in the executive can incorporate other implicit rewards of the position into the desired level of compensation.

Wang, Venezia and Lou (2013), identified several variables that are associated with CEO compensation. Their results show that CEO tenure, age, duality and gender, which served as control variables explained $4.1 \%$ of the variability in CEO compensation. Their predictor variables: international diversification, industrial diversification, investment opportunities, accounting-based performance, firm size and stock ownership were significant in explaining CEO compensation (33\%). Market-based performance did not seem to affect CEO compensation of their sample firms. Of the predictor variables, industrial diversification and stock ownership have a negative impact on CEO compensation.

Victoravich, Xu and Gan (2012) show that not only does institutional ownership affect executive compensation in the banking industry, but the nature of institution has an impact on the composition of the compensation. Their results indicate a positive relationship between the percent of top five institutional investors and total executive compensation and equity-based compensation. However, their studies also find that the top five institutional investors have a negative impact on the level of bonus compensation in the study sample. They classified Institutional ownership as passive versus active depending on whether they are in banks and insurance firms (passive) or investment companies and independent investment advisers (active). Their results show that the level of total compensation tends to increase while CEO bonus compensation decreases when the largest institutional investor is active. Their results for passive investors is similar to active, albeit weak.

Lin, Kuo and Wang (2013) used CEO tenure, CEO age, CEO shareholdings, Board size, firm size, and firm performance to examine their effect on CEO compensation and the "fat cat CEO" concept. Their analysis, using the S\&P 500, 400 and 600 firms, show that these variables (with the exception of firm performance as measured by ROE and ROA) have a positive effect on CEO compensation, including CEOs of the "Fat Cat "firms.

Ayadi and Boujèlbène (2013) examined the determinants of executive compensation in the European banking industry. They show that board size, board independence, firm size and return on equity have a positive effect on executive compensation. In a regression model in which CEO duality was the only board characteristic explanatory variable, they find that it had a positive and highly significant impact on CEO compensation.

Collin et al (2014) studied the effect of the identity of the owners on the level and composition of executive compensation based on Swedish firms. They show that the characteristics of the owners do affect both the level of executive compensation and the use of stock options. Saucer, Schneider and Sheikh (2013) show that the classification of a firm as sin and non-sin firm affects the level of executive compensation, with sin firms earning higher compensations than non-sin firms.

Several of the studies on executive compensation have focused on the variables that seem to explain the variation in the level and mix of compensation received by top executives. Fleming and Schaupp (2012) follow a different approach by asking for what should determine executive compensation. In a survey of executive and non-executive investors on the determinants of executive compensation, they find that non-executive investors placed greater emphasis on performance factors whereas executive investors emphasized human capital factors. 
They define human capital attributes as industry and general knowledge. Industry knowledge was based on the length of time as CEO and length of time with the company, the industry, company stock ownership, and the market capitalization of the firm. General knowledge was measured as the experience and education of the executive as well as the total dollar value of the firm's assets. They also describe a third determinant of executive compensation based on firm performance. This factor comprises stock performance, asset efficiency, equity efficiency, and market dominance. On the other hand, non-executive investors believed that firm performance as measured by return on equity, firm cash flow and net income, firm growth rate and stock performance should be the basis for executive compensation. In addition, human capital as measured by the CEO's experience, education, tenure as well as firm size and market capitalization should influence executive compensation.

Lin and Lin (2014) focus on the interplay between board compensation and executive compensation. After correcting for the effects of firm size, firm performance, industry and general economic conditions, they find the existence of "mutual back scratching" with higher CEO compensation when board compensation is high. IN addition, they find that CEO tenure, CEO age, board size, and firm size, are positively related to executive compensation, whereas $\mathrm{CEO}$ director-dummy variable, $\mathrm{CEO}$ shareholdings are negatively related to $\mathrm{CEO}$ compensation. However, they do not find a significant relation with firm performance as measured by ROE or ROA.

Dah, Abosedra and Matar (2012) in their examination of the relationship between equity based compensation (EBC) and firm value (as measured by Tobin's Q) document a positive relationship between firm value and EBC, sales-to-asset ratio, CEO level of entrenchment, percentage of independent directors, return on assets and research and development expenditure. Their results also indicate that board size has a negative effect on firm value.

Armstrong, Ittner and Larcker (2012) studied the relationship between executive compensation, corporate governance and compensation consultants. Using number of directors, percentage of outside directors, percentage of board members above age sixty-nine, percentage of board members serving on at least two other boards, a dummy variable representing the use or not of an outside chairman, percentage of outside directors, and percentage of outside directors appointed after the current CEO as a measure of corporate governance, their results indicate that economic variables explained $71 \%$ of the variability in CEO compensation, with an additional $1.3 \%$ coming from corporate governance variables. Their analysis indicates that there seems to be an inverse relationship between corporate governance and CEO compensation. Their study also shows that the weaker the corporate governance of the firm, the greater the propensity to use outside compensation consultants.

Weiss (2011) discusses the different paradigm on the executive compensation literature. The two main theories on executive compensation are the pay-for-performance and managerial power paradigms. Weiss argues that "the correlation between pay and performance and the magnitude of compensation have different implication with respect to the efficacy of executive pay." He points out that on a pay-for-performance based on market return, in an efficient market, only the "changes in the firm value attributed to the CEO's actions over her tenure reflect positive and negative surprises." Consequently, in an informed market the response to the hire of a new CEO will reflect all the expected benefits and costs, hence there would not be any relation between actual pay and abnormal performance over the CEO's tenure. Furthermore, Weiss points out the irregularities that exist both at the beginning and at the end of the tenure term. He notes that "investors view turnover announcements as good news presaging performance improvements."

\section{Data and Methodology}

The data for this study on ADI and LHI are obtained from Morningstar Direct company database in February 2015. Ayadi and Boujèlbène (2013) groups the determinants of executive compensation into two main categories: Board attributes, and firm performance. Following their study, we examine the effect of size of the board, independence of the board, institutional ownership, insider ownership, and CEO-Chair duality. In addition, we use stock return, sales growth and return on equity as measures of firm performance. CEO compensation is normalized by total assets and the natural log of total asset is used to control for size effect. Aside from CEO compensation, we also look at the total executive compensation. Dummy variables are used to account for industry effect. In addition, the impact of executive compensation on sales, profitability and stock return were also explored. Equations 1 through 6 shows the models estimated.

$$
\begin{aligned}
& Y_{1}=\alpha_{1}+\beta_{11} X_{1}+\beta_{12} X_{2}+\beta_{13} X_{3}+\beta_{14} X_{4}+\beta_{15} X_{5}+\beta_{16} X_{6}+\beta_{17} X_{7}+\beta_{18} X_{8}+\beta_{19} X_{9}+\varepsilon_{1} \\
& Y_{2}=\alpha_{2}+\beta_{21} X_{1}+\beta_{22} X_{2}+\beta_{23} X_{3}+\beta_{24} X_{4}+\beta_{25} X_{5}+\beta_{26} X_{6}+\beta_{27} X_{7}+\beta_{28} X_{8}+\beta_{29} X_{9}+\varepsilon_{2} \\
& Y_{3}=\alpha_{3}+\beta_{31} X_{1}+\beta_{32} X_{2}+\beta_{33} X_{3}+\beta_{34} X_{4}+\beta_{35} X_{5}+\beta_{36} X_{6}+\beta_{37} X_{7}+\beta_{38} X_{8}+\beta_{39} X_{9}+\varepsilon_{3}
\end{aligned}
$$




$$
\begin{aligned}
X_{3}= & \alpha_{4}+\beta_{41} X_{1}+\beta_{42} X_{2}+\beta_{2} Y_{2}+\beta_{1} Y_{1}+\beta_{44} X_{4}+\beta_{45} X_{5}+\beta_{46} X_{6}+\beta_{47} X_{7}+\beta_{48} X_{8}+\beta_{49} X_{9}+\varepsilon_{4} \\
X_{2}= & \alpha_{5}+\beta_{51} X_{1}++\beta_{3} Y_{2}+\beta_{4} Y_{1}++\beta_{54} X_{4}+\beta_{55} X_{5}+\beta_{56} X_{6}+\beta_{57} X_{7}+\beta_{58} X_{8}+\beta_{59} X_{9}+\varepsilon_{5} \\
& X_{4}=\alpha_{6}+\beta_{61} X_{1}+\beta_{5} Y_{2}+\beta_{6} Y_{1}+\beta_{65} X_{5}+\beta_{66} X_{6}+\beta_{67} X_{7}+\beta_{68} X_{8}+\beta_{69} X_{9}+\varepsilon_{6}
\end{aligned}
$$

Where:

$\mathrm{Y}_{1}$ is the ratio of CEO compensation to total assets (CEO/TA)

$\mathrm{Y}_{2}$ is the ratio of total executive compensation to total assets (TExec/TA)

$\mathrm{Y}_{3}$ is the percentage change in CEO compensation (\%ChgInCEOCp)

$\mathrm{X}_{1}$ is Percentage institutional ownership (\%Inst)

$\mathrm{X}_{2}$ is Sales growth (SalesGr)

$\mathrm{X}_{3}$ is the Firm's stock market performance (StockReturn)

$\mathrm{X}_{4}$ is the Return on Equity based on Net Income (NIROE)

$\mathrm{X}_{5}$ is the number of Independent Directors (\#IDirs)

$\mathrm{X}_{6}$ is the Natural log of Total Assets ( $\left.\log \mathrm{TA}\right)$

$\mathrm{X}_{7}$ is the industry dummy variable (IndDummy)

$\mathrm{X}_{8}$ is the Dual Chairman and CEO position dummy variable (CHCEDummy)

$\mathrm{X}_{9}$ is percentage of insider ownership (\%Insider)

\section{Results}

Tables 1 to 6 displays the results of the regression analysis of the six (6) equations/models. Each table comprises three (3) panels. Panel A shows a summary of the results; panel B is the ANOVA results while panel C shows the regression coefficients for the model. In table 1, the dependent variable is the CEO/TA variable. The results show that the model has an adjusted R-squared of 0.64, with an F-statistic of 15.405. Despite the strong explanatory power of the model, it shows that there is a weak significant difference in the relative compensation of the CEOs between the two industries. The industry dummy variable had a t-value of -1.136 , significant at $26 \%$ level. The negative sign implies that there exists a weak influence of the industry that tends to reduce the relative compensation of the CEO in the Aerospace/Defense industry. The negative coefficient might suggest that executive compensation could play a minor role in contract awards in the defense industry. The results also indicate that the relative CEO compensation is a strong function of the size as measured by total assets, sales growth and joint $\mathrm{CEO} / \mathrm{Chairman}$ title. However, only the sales growth variable had a positive effect on CEO compensation. The effect of size as measured by the $\log \mathrm{TA}$ was very significant at $\mathrm{t}=-5.052$ and a $\mathrm{p}$-value of 0.0 . Thus, CEO compensation when normalized with total assets seems to have an inverse relationship with the size

\begin{tabular}{|c|c|c|c|c|}
\hline \\
\hline \multicolumn{5}{|c|}{$\begin{array}{l}\text { Panel A: Model Summary } \\
\text { Model }\end{array}$} \\
\hline 1 & $.827^{\mathrm{a}}$ & .684 & .640 & .4716820 \\
\hline
\end{tabular}
of the firm.

Table 1. Dependent Variable: CEO/TA

\section{Panel B: ANOVA ${ }^{\text {a }}$}

\begin{tabular}{llllll}
\hline Model & & Sum of Squares & df & Mean Square & F \\
\hline 1 & Regression & 30.845 & 9 & 3.427 & 15.405 \\
& Residual & 14.239 & 64 & .222 & $.000^{\mathrm{b}}$ \\
& Total & 45.084 & 73 & & \\
\hline
\end{tabular}

a. Dependent Variable: CEO/TA

b. Predictors: (Constant), \%Inst, IndDummy, Sales Gr., Stock Ret., ChCEODummy, \%Insider, NI ROE, \# of I. Dirs, Log TA 
Panel C: Coefficients ${ }^{\mathrm{a}}$

\begin{tabular}{|c|c|c|c|c|c|c|}
\hline \multirow[b]{2}{*}{ Mode } & & \multicolumn{2}{|c|}{ Unstandardized Coefficients } & $\begin{array}{l}\text { Standardized } \\
\text { Coefficients }\end{array}$ & \multirow[b]{2}{*}{$\mathrm{t}$} & \multirow[b]{2}{*}{ Sig. } \\
\hline & & $\mathrm{B}$ & Std. Error & Beta & & \\
\hline \multirow[t]{10}{*}{1} & (Constant) & 2.033 & .318 & & 6.402 & .000 \\
\hline & ChCEODummy & -.265 & .125 & -.169 & -2.113 & .039 \\
\hline & IndDummy & -.141 & .124 & -.088 & -1.136 & .260 \\
\hline & $\log \mathrm{TA}$ & -.229 & .045 & -.611 & -5.052 & .000 \\
\hline & \# of I. Dirs & .052 & .037 & .160 & 1.413 & .162 \\
\hline & Sales Gr. & .007 & .001 & .619 & 7.898 & .000 \\
\hline & Stock Ret. & -.001 & .001 & -.040 & -.466 & .643 \\
\hline & NI ROE & .001 & .002 & .021 & .232 & .818 \\
\hline & \%Insider & -.022 & .014 & -.151 & -1.537 & .129 \\
\hline & $\%$ Inst & -.001 & .002 & -.021 & -.252 & .802 \\
\hline
\end{tabular}

a. Dependent Variable: CEO/TA

In table 2, the dependent variable is the T.ExecTA, the relative total executive compensation. In this case, like CEO compensation, the size and sales growth variable were the dominant explanatory variable. However, the significance of the industry effect was significantly weaker, at $86 \%$ as compared to $26 \%$. Table 3 is the regression results with the growth rate in CEO compensation as the dependent variable. The model has a very weak explanatory power with a p-value of $25.6 \%$. It also shows that the percent insider ownership had a negative $(\mathrm{t}=-2.69)$ but significant effect (.009) on the rate of increase in the CEO compensation. The industry variable did not have significant effect. As with CEO compensation, the effect of total asset on total executive compensation was strong and negative with a $t$-value of -5.577 and $p$-value of 0.000 .

Table 2. Dependent Variable: T. Exec/TA

\begin{tabular}{|c|c|c|c|c|}
\hline \multicolumn{5}{|c|}{ Panel A: Model Summary } \\
\hline Model & $\mathrm{R}$ & R Square & Adjusted R Square & Std. Error of the Estimate \\
\hline 2 & $.777^{\mathrm{a}}$ & .604 & .548 & .9333759 \\
\hline
\end{tabular}

Panel B: ANOVA ${ }^{\mathrm{a}}$

\begin{tabular}{cccccc}
\hline & Model & Sum of Squares & df & Mean Square & Sig. \\
\hline 2 & Regression & 84.865 & 9 & 9.429 & $.000^{\mathrm{b}}$ \\
& Residual & 55.756 & 64 & .871 & 10.824 \\
Total & 140.621 & 73 & & \\
\hline
\end{tabular}

a. Dependent Variable: T.Exec/TA

b. Predictors: (Constant), \%Inst, IndDummy, Sales Gr., Stock Ret., ChCEODummy, \%Insider, NI ROE, \# of I. Dirs, Log TA

Panel C: Coefficients ${ }^{\mathrm{a}}$

\begin{tabular}{|c|c|c|c|c|c|c|}
\hline \multirow[b]{2}{*}{ Mode } & & \multicolumn{2}{|c|}{ Unstandardized Coefficients } & $\begin{array}{l}\text { Standardized } \\
\text { Coefficients }\end{array}$ & \multirow[b]{2}{*}{$\mathrm{t}$} & \multirow[b]{2}{*}{ Sig. } \\
\hline & & $\mathrm{B}$ & Std. Error & Beta & & \\
\hline \multirow[t]{9}{*}{2} & (Constant) & 4.480 & .628 & & 7.129 & .000 \\
\hline & ChCEODummy & -.398 & .248 & -.143 & -1.603 & .114 \\
\hline & IndDummy & -.044 & .246 & -.015 & -.177 & .860 \\
\hline & $\log \mathrm{TA}$ & -.500 & .090 & -.756 & -5.577 & .000 \\
\hline & \# of I. Dirs & .082 & .073 & .142 & 1.120 & .267 \\
\hline & Sales Gr. & .008 & .002 & .425 & 4.839 & .000 \\
\hline & Stock Ret. & -.003 & .003 & -.086 & -.898 & .372 \\
\hline & NI ROE & .003 & .004 & .061 & .605 & .547 \\
\hline & \%Insider & -.025 & .028 & -.097 & -.877 & .384 \\
\hline
\end{tabular}


Tables 4 through 6 explores the effect of industry and executive compensation on the performance of the firm. Table 4 presents the regression results for the Stock Return. The results indicate that market response to the firms is strongly dependent on the industry. The model has an adjusted R-squared of $24 \%$. The industry variable has a $\mathrm{t}$-value of 2.738 and a $\mathrm{p}$-value of 0.008 . In addition, the \%Insider and the return on equity were shown to be strong influence ( $\mathrm{t}$-values of 3.681 and 3.554 , respectively) on the firm's stock returns.

Table 3. Dependent Variable: \%ChgInCEOCp

\begin{tabular}{|c|c|c|c|c|}
\hline \multicolumn{5}{|c|}{ Panel A: Model Summary } \\
\hline \multirow[b]{2}{*}{ Model } & \multirow[b]{2}{*}{$\mathrm{R}$} & \multirow[b]{2}{*}{ R Square } & \multirow[b]{2}{*}{ Adjusted R Square } & Std. Error \\
\hline & & & & Estimate \\
\hline 3 & $.393^{\mathrm{a}}$ & .154 & .035 & 220.74421 \\
\hline \multicolumn{5}{|c|}{$\begin{array}{l}\text { a. Predictors: (Constant), \%Inst, IndDummy, Sales Gr., Stock Ret., ChCEODummy, \%Insider, NI } \\
\text { ROE, \# of I. Dirs, Log TA }\end{array}$} \\
\hline
\end{tabular}

\section{Panel B: ANOVA}

\begin{tabular}{lllllll}
\hline Model & & Sum of Squares & df & Mean Square & F & Sig. \\
\hline 3 & Regression & 568970.126 & 9 & 63218.903 & 1.297 & $.256^{\text {b }}$ \\
& Residual & 3118592.471 & 64 & 48728.007 & & \\
& Total & 3687562.596 & 73 & & & \\
\hline
\end{tabular}

a. Dependent Variable: \% Chg In CEO Cp

b. Predictors: (Constant), \%Inst, IndDummy, Sales Gr., Stock Ret., ChCEODummy, \%Insider, NI ROE, \# of I. Dirs, Log TA

\section{Panel C: Coefficients ${ }^{\mathrm{a}}$}

\begin{tabular}{|c|c|c|c|c|c|c|}
\hline \multirow[b]{2}{*}{ Mode } & & \multicolumn{2}{|c|}{ Unstandardized Coefficients } & $\begin{array}{l}\text { Standardized } \\
\text { Coefficients }\end{array}$ & \multirow[b]{2}{*}{$\mathrm{t}$} & \multirow[b]{2}{*}{ Sig. } \\
\hline & & $\mathrm{B}$ & Std. Error & Beta & & \\
\hline \multirow[t]{10}{*}{3} & (Constant) & 98.681 & 148.611 & & .664 & .509 \\
\hline & ChCEODummy & -49.418 & 58.655 & -.110 & -.843 & .403 \\
\hline & IndDummy & 19.537 & 58.174 & .043 & .336 & .738 \\
\hline & $\log \mathrm{TA}$ & 24.602 & 21.202 & .230 & 1.160 & .250 \\
\hline & \# of I. Dirs & -2.915 & 17.357 & -.031 & -.168 & .867 \\
\hline & Sales Gr. & .104 & .391 & .034 & .266 & .791 \\
\hline & Stock Ret. & -.387 & .665 & -.082 & -.582 & .562 \\
\hline & NI ROE & .845 & 1.010 & .124 & .837 & .406 \\
\hline & \%Insider & -3.822 & 6.710 & -.092 & -.570 & .571 \\
\hline & \%Inst & -2.772 & 1.030 & -.366 & -2.690 & .009 \\
\hline
\end{tabular}

a. Dependent Variable: \% Chg In CEO Cp.

The regression model results with sales growth as the dependent variable is shown in table 5. This model has an adjusted R-squared of $65.3 \%$ with an F-value of 16.243 . The CEO/TA variable was the only statistically significant explanatory variable with a t-value of 7.947 . The industry variable was marginally significant at $17.8 \%$, with a t-value of 1.362 . In addition, the return on equity variable was significant at $13.2 \%$, with a t-value of -1.526 while the chairman and CEO dual appointment was significant at $20.1 \%$ with a t-value of 1.292 .

Table 4. Dependent variable: stock return

Panel A: Model Summary

\begin{tabular}{|c|c|c|c|c|}
\hline Model & $\mathrm{R}$ & R Square & Adjusted R Square & Std. Error of the Estimate \\
\hline 4 & $.587^{\mathrm{a}}$ & .344 & .240 & 41.25970 \\
\hline
\end{tabular}


Panel B: ANOVA ${ }^{\mathrm{a}}$

\begin{tabular}{lllllll}
\hline Model & & Sum of Squares & df & Mean Square & F & Sig. \\
\hline 4 & Regression & 56337.493 & 10 & 5633.749 & 3.309 & $.002^{\mathrm{b}}$ \\
& Residual & 107248.840 & 63 & 1702.363 & & \\
& Total & 163586.333 & 73 & & & \\
\hline
\end{tabular}

a. Dependent Variable: Stock Ret.

b. Predictors: (Constant), T.Exec/TA, ChCEODummy, \%Insider, IndDummy, NI ROE, \%Inst, Sales Gr., \# of I. Dirs, Log TA, CEO/TA

\section{Panel C: Coefficients ${ }^{\mathrm{a}}$}

\begin{tabular}{|c|c|c|c|c|c|c|}
\hline \multirow[b]{2}{*}{ Mode } & & \multicolumn{2}{|c|}{ Unstandardized Coefficients } & \multicolumn{2}{|l|}{$\begin{array}{l}\text { Standardized } \\
\text { Coefficients }\end{array}$} & \multirow[b]{2}{*}{ Sig. } \\
\hline & & $\mathrm{B}$ & Std. Error & Beta & $\mathrm{t}$ & \\
\hline \multirow[t]{11}{*}{4} & (Constant) & -7.326 & 37.239 & & -.197 & .845 \\
\hline & ChCEODummy & 8.307 & 11.363 & .088 & .731 & .467 \\
\hline & IndDummy & 29.572 & 10.799 & .307 & 2.738 & .008 \\
\hline & $\log \mathrm{TA}$ & 2.744 & 4.821 & .122 & .569 & .571 \\
\hline & \# of I. Dirs & -1.642 & 3.294 & -.083 & -.498 & .620 \\
\hline & Sales Gr. & .031 & .119 & .048 & .262 & .794 \\
\hline & NI ROE & .618 & .174 & .430 & 3.554 & .001 \\
\hline & \%Insider & 4.332 & 1.177 & .493 & 3.681 & .000 \\
\hline & $\%$ Inst & .092 & .192 & .058 & .480 & .633 \\
\hline & $\mathrm{CEO} / \mathrm{TA}$ & 27.441 & 28.737 & .456 & .955 & .343 \\
\hline & T.Exec/TA & -17.698 & 14.456 & -.519 & -1.224 & .225 \\
\hline
\end{tabular}

a. Dependent Variable: Stock Ret.

Table 6 presents the regression results with return on equity as the dependent variable. It shows that the model has an adjusted R-squared of $17.2 \%$ and an F-statistic of 2.895 and a p-value of 0.008 . The most significant explanatory variable for this model is the CEO compensation, with a significance of 0.02 and a t-statistic of -2.38 . Other marginally significant variables are the total executive compensation, percentage of insider ownership and the number of independent directors with t-statistics of $1.657,-1.584$ and 1.595 , respectively.

Table 5. Dependent variable: SalesGr

Panel A: Model Summary

\begin{tabular}{lllll}
\hline Model & R & R Square & Adjusted R Square & Std. Error of the Estimate \\
\hline 5 & $.834^{\mathrm{a}}$ & .696 & .653 & 43.39005 \\
\hline
\end{tabular}

a. Predictors: (Constant), T.Exec/TA, ChCEODummy, \%Insider, IndDummy, NI ROE, \%Inst, \# of I. Dirs, Log TA, CEO/TA

\section{Panel B: ANOVA ${ }^{\mathrm{a}}$}

\begin{tabular}{lllllll}
\hline Model & & Sum of Squares & df & Mean Square & F & Sig. \\
\hline 5 & Regression & 275224.840 & 9 & 30580.538 & 16.243 & \\
& Residual & 120492.563 & 64 & 1882.696 & \\
& Total & 395717.402 & 73 & & \\
\hline
\end{tabular}

a. Dependent Variable: Sales Gr.

b. Predictors: (Constant), T.Exec/TA, ChCEODummy, \%Insider, IndDummy, NI ROE, \%Inst, \# of I. Dirs, Log TA, CEO/TA 


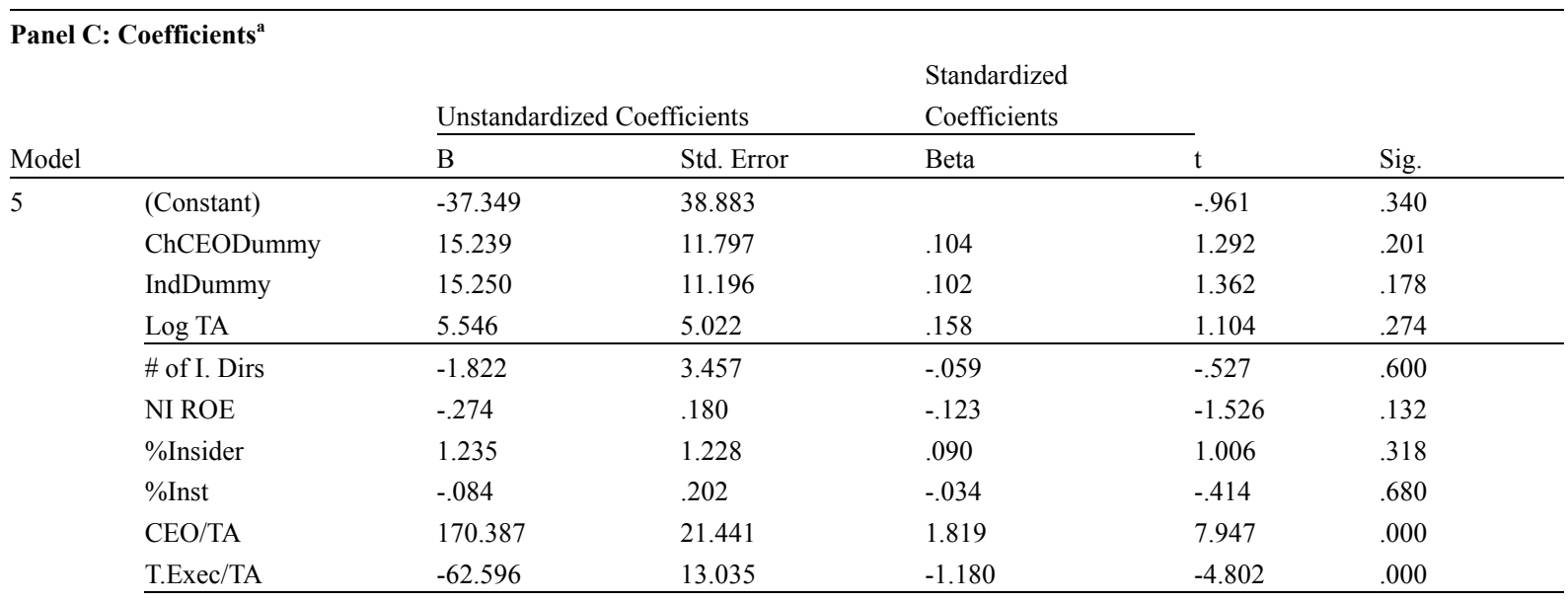

a. Dependent Variable: Sales Gr.

Table 6. Dependent Variable: NI ROE

Panel A: Model Summary

\begin{tabular}{lllll}
\hline Model & $\mathrm{R}$ & $\mathrm{R}$ Square & Adjusted R Square & Std. Error of the Estimate \\
\hline 6 & $.513^{\mathrm{a}}$ & .263 & .172 & 29.96635 \\
\hline
\end{tabular}

a. Predictors: (Constant), T.Exec/TA, ChCEODummy, \%Insider, IndDummy, \%Inst, \# of I. Dirs, Log TA, CEO/TA

\section{Panel B: ANOVA}

\begin{tabular}{lllllll}
\hline Model & & Sum of Squares & df & Mean Square & F & Sig. \\
\hline 6 & Regression & 20798.764 & 8 & 2599.846 & $.008^{\mathrm{b}}$ & \\
& Residual & 58368.851 & 65 & 897.982 & \\
& Total & 79167.615 & 73 & & \\
\hline
\end{tabular}

a. Dependent Variable: NI ROE

b. Predictors: (Constant), T.Exec/TA, ChCEODummy, \%Insider, IndDummy, \%Inst, \# of I. Dirs, Log TA, CEO/TA

Panel C: Coefficients ${ }^{\mathrm{a}}$

\begin{tabular}{|c|c|c|c|c|c|c|}
\hline \multirow[b]{2}{*}{ Mode } & & \multicolumn{2}{|c|}{ Unstandardized Coefficients } & $\begin{array}{l}\text { Standardized } \\
\text { Coefficients }\end{array}$ & \multirow[b]{2}{*}{$\mathrm{t}$} & \multirow[b]{2}{*}{ Sig. } \\
\hline & & $\mathrm{B}$ & Std. Error & Beta & & \\
\hline \multirow[t]{9}{*}{6} & (Constant) & -8.302 & 26.834 & & -.309 & .758 \\
\hline & ChCEODummy & 1.732 & 8.144 & .026 & .213 & .832 \\
\hline & IndDummy & -5.820 & 7.698 & -.087 & -.756 & .452 \\
\hline & $\log \mathrm{TA}$ & -.418 & 3.468 & -.027 & -.121 & .904 \\
\hline & \# of I. Dirs & 3.736 & 2.342 & .271 & 1.595 & .116 \\
\hline & \%Insider & -1.318 & .832 & -.216 & -1.584 & .118 \\
\hline & \%Inst & .132 & .139 & .119 & .954 & .344 \\
\hline & $\mathrm{CEO} / \mathrm{TA}$ & -33.794 & 14.202 & -.806 & -2.380 & .020 \\
\hline & T.Exec/TA & 14.612 & 8.818 & .616 & 1.657 & .102 \\
\hline
\end{tabular}

This study supports previous studies (Wang, Venezia and Lou (2013); Lin, Kuo and Wang (2013); Ayadi and Boujelbene (2013)) on executive compensation by showing the significance of insider ownership, duality, size, number of independent directors and sales growth on both executive and CEO compensation in the ADI and LHI industries. The significant and positive effect of sales growth on CEO compensation draws attention to the role of sales growth as the primary responsibility of the CEO. This, coupled with the lack of significance of the size variable implies that growth by acquisition that only increases the size of the firm will not be rewarded.

This study also highlights the importance of industry specific factors in stock valuation and returns through the highly significant effect of the industry dummy variable on the stock return regression. The positive significant effect of percent insider stock ownership on stock return is an indication of the reduction of agency conflict resulting from the separation of ownership and control. In addition, the negative effect of insider ownership on 
executive compensation while positive on stock returns shows that re-alignment of executive's pay with the interest of the owners.

The incentive effect of CEO compensation on firm performance is supported by the positive and significant effect of the CEO/TA variable on sales growth. The study also points to the dual effect of executive compensation. Total executive compensation has an incentivizing effect on return on equity. However, in effect of the CEO compensation alone has a negative effect on the return on equity. This seeming contradiction might be because CEO compensation is included in the total executive compensation.

This study contributes to the literature by showing directly that executive compensation could vary by industry in apparent support of Wang, Venezia and Lou (2013) that found that firms with multiple industry classification had a lower executive compensation than those with single industry classification. It also provides additional evidence on multi-factor asset pricing models and the concept of strategic beta.

This study also indicates that Congress could be indirectly affecting the compensation of the executives in the industries that rely on government by affecting the size and nature of contract awarded to the firms. In addition, the study provides further evidence on the factors that affect and determine the compensation of executives are market and operations based as such congress should desist from tampering with it. This study provides evidence that managers should focus on sales growth and take on significant ownership positions with their firm to enhance their wealth as measured by the firm's stock performance.

\section{Conclusion}

The primary objective of this study was to investigate if there is a difference in the executive compensation between the Aerospace/Defense industry and the Leisure and hospitality industry that might be attributed to the impact of congressional power and concern over executive compensation in an industry, Aerospace/Defense, that is heavily dependent on government contract for its livelihood and existence. The results of this study indicates that despite the public outcry and reactions from congress, that there is a weak negative effect on the executive compensation of the ADI through possible contract negotiations and awards relative to compensations in the LHI. However, the executive compensations are largely dependent on market factors as is the case in other industries. The study also shows the negative effect of size on a normalized compensation. It demonstrates that executive compensation, in relative terms, decreases with the size of the firm as measured by total assets. Finally, this study has a very narrowly defined focus. It examined if there is a significant difference in executive compensation between two dissimilar industries. No attempt was made to isolate the effect of each variable by eliminating or examining the effect of correlation between the variables.

\section{References}

Aerospace and defense industry market research \& statistics. Retrieved November 23, 2014 from http://www.reportlinker.com/ci02321/Aerospace-and defense.htm1

Armstrong, C. S., Ittner, C. D., \& Larcker, D. F. (2012). Corporate governance, compensation consultants, and CEO pay levels. Review of Accounting Studies, 17(2), 322-351. https://doi.org/10.1007/s11142-012-9182-y

Ayadi, N., \& Boujèlbène,Y. (2013). The Influence of the Board of Directors on the Executive Compensation in the banking industry. Global Business and Management Research: An International Journal, 5(2), 83-90.

Balsam, S., \& Harris, E. E. (2014). The impact of CEO compensation on nonprofit donations. The Accounting Review, 89(2), 425-450. https://doi.org/10.2308/accr-80631

Boerner, H. (2013). Corporate Executive Compensation: The public dialogue over recent decades. Corporate Finance Review, 18(1), 32-37.

Collin, S. Y., Gustafsson, L., Perersson, E., \& Smith, E. (2014). Options are a CEO's best friend: Executive Compensation in Swedish listed corporations. The JUP Journal of Corporate Governance, XIII(3), 40-71.

Dah, A. M., Abosedra, S. S., \& Matar, G. F. (2012). CEO compensation and firm value. Journal of Business \& Economics Research.

Fleming, A. S., \& Schaupp, L. C. (2012). Factor analysis of executive compensation determinants: Survey evidence from executives and non-executive investors. Corporate Governance, 12(1), 16-41. https://doi.org/10.1108/14720121191319

Ims, K. J., Pedersen, L. J. T., \& Zsolnai, L. (2013). How economic incentives may destroy social, ecological and existential values: The case of Executive Compensation. $J$ Bus Ethics, 123, 353-360. https://doi.org/10.1007/s10551-013-1844-6 
Industries at a glance: Accommodation and food services; NAICS 72. Retrieved February 23, 2015 from http://www.bls.gov/iag/tgs/iag72.htm

Lin, D., \& Lin, L. (2014). The interplay between Director compensation and CEO compensation. The International Journal of Business and Finance Research, 8(2), 11-26.

Lin, D., Kuo, H., \& Wang, L. (2013). Chief Executive Compensation: an empirical study of fat cat CEOs. The International Journal of Business and Finance Research, 7(2), 27-42.

PricewaterhouseCoopers LLP (PWC). Hospitality \& Leisure. Retrieved February 23, 2015 from http://www.pwc.com/us/en/asset-management/hospitality-leisure/index.jhtm1

Saueer, D.A., Schneider, G. P., \& Sheikh, A. (2013). The wages of sin: Social norms and executive compensation. Journal of Legal, Ethical and Regulatory Issues, 16(1), 47-59.

Siegel, M. L. (2014). Industry Analysis: Aerospace and Defense. Retrieved November 23, 2014 from http://www.valueline.com/Stocks/Industries/Industry_analysis_/Aerisoece_Defense

U.S. Bureau of labor Statistics. Arts, Entertainment, and Recreation: NAICS 71. Retrieved November 23, 2014 from http://data.bls.gov/cgi-bin/print.pl/iag/tgs/iag71.htm

U.S. Bureau of labor Statistics. Industries at a glance; leisure and hospitality. Retrieved November 23, 2014 from http://data.bls.gov/cgi-bin/print.pl/iag/tgs/iag70.htm

Victoravich, L. M., Xu, P., \& Gan, H. (2012). Institutional ownership and executive compensation: Evidence for US banks during the financial crisis. Managerial Finance, 39(1), 28-46. https://doi.org/10.1108/03074351311283559

Wang, H. C., Venezia, C. C., \& Lou, Y. (2013). Determinants of Chief Executive Officer Compensation. The International Journal of Business and Finance Research, 7(4), 29-42.

Weiss, D. (2011). Examining Shareholder value creation over CEO tenure: A new approach to testing effectiveness of Executive compensation. Journal of Management Accounting Research, 23, 29-36. https://doi.org/10.2308/jmar-10106

Willard, W. (2014). Throwing out the baby and weighing the bathwater: The nonsense of Executive compensation oversight. Cornell HE Review, 1-12; http://digitalcommons.ilr.cornell.edu/cgi/viewcontent.cgi\%3Farticle\%3D1053\%26context\%3Dchrr

\section{Copyrights}

Copyright for this article is retained by the author(s), with first publication rights granted to the journal.

This is an open-access article distributed under the terms and conditions of the Creative Commons Attribution license (http://creativecommons.org/licenses/by/4.0/). 